\section{Counter the risk of Alzheimer's transfer}

You urgently call for sterilization procedures that can destroy possible protein 'seeds' of Alzheimer's disease on medical instruments (Nature 531, 294-297; 2016). In fact, a proof of principle for such technology is in place and promises to allay fears of surgical transmission.

The process entails adapting an assay for the transmission risk of pathological prion proteins that are deposited on instruments after surgery. A team at the Robert Koch Institute - a governmental body that safeguards public health - used this approach to develop precautionary sterilization procedures (see M. Beekes et al. Acta Neuropathol. 128, 463-476; 2014) against protein aggregates known to be associated with Alzheimer's and Parkinson's pathologies (A. Thomzig et al. Acta Neuropathol. Commun. 2, 151; 2014).

The researchers tested different experimental or commercial instrument cleaners that are effective against prions, followed by steam sterilization. They found that in crude humanbrain suspensions that were attached to steel-wire grids acting as instrument surrogates, this treatment combination removed amyloid- $\beta$, tau and $\alpha$-synuclein protein aggregates, as indicated by western blotting.

Michael Beekes, Achim Thomzig Robert Koch Institute, Germany. beekesm@rki.de

\section{Fanning the flames of Australian wildfires}

Climate change will increase the frequency, intensity and scale of Australian bushfires, at huge cost to its population and unique biota. Yet the government-funded science agency, CSIRO, plans to cut at least 100 jobs in climate research. Australia urgently needs political leadership on climate action and investment in climate science (see also D. Lindenmayer
Nature 531, 305; 2016).

For example, fires last year burned an estimated $90 \%$ of the habitat occupied by the critically endangered marsupial Gilbert's potoroo (Potorous gilbertii) and the western ground parrot (Pezoporus flaviventris; go.nature. com/ogriue). The affected areas also contain six other endemic threatened plant and animal species. Their already small and isolated remnant populations are now even more vulnerable.

In Victoria alone, 4.3 million hectares of eucalypt forest burned in 2003-14, comparable to the entire area destroyed over the previous 50 years (T. A. Fairman et al. Int. J. Wildland Fire http:// doi.org/bdkt; 2015). Moreover, modelling for southeastern Australia predicts 5-25\% increases in fire risk by 2050 compared with 1974-2003 (see go.nature.com/xmpj8z).

Australia's ill-advised reduction of its climate-science capacity will severely compromise its ability to respond to this growing threat. Tim S. Doherty Deakin University, Victoria, Australia. Martine Maron The University of Queensland, Brisbane, Australia. tim.doherty.0@gmail.com

\section{EU cash goes to the sticky and attractive}

Winning European research money does not depend only on a well-funded research base (G. Parisi Nature 530, 33; 2016). We find that it is also contingent on national governments' ability to retain their own scientists

('stickiness') and to attract others from abroad ('attractiveness').

We analysed statistical indicators of EU scientists' mobility for 2007-14 (http:// erc.europa.eu and go.nature. com/bpeylu) to determine the stickiness and attractiveness of different countries. We quantified attractiveness and stickiness as the relative difference between the numbers of incoming or remaining researchers, respectively, and of outgoing ones.
For both measures, we found that the higher the value, the better were that country's chances of securing European research funding. The United Kingdom and Sweden are examples of high scorers in both; Italy is among the lowest (see go.nature.com/wyvtls).

We conclude that there is a 'richget-richer' effect for countries that have high attractiveness and stickiness scores. Those nations also boast a high gross domestic product per capita and tend to invest more in research and development. This means that they can lure and retain the best researchers by providing competitive salaries and a guaranteed future in research. Manlio De Domenico, Alex Arenas Rovira I Virgili University, Tarragona, Spain. manlio.dedomenico@urv.cat

\section{One of animal-study criteria backfires}

Applications for animal studies in the European Union have become weightier and more informative since the EU's animal protection act was adopted in 2010. Because applications are now more challenging to review, researchers in some German states are charged a processing fee. This seems to run counter to the act's unifying approach, because no fee is levied from animal researchers in other EU countries.

Fees vary according to the burden of reviewing. For example, the charge for a 30-page application, which currently takes 3-4 months to review, might be $€ 1,000$ (US $\$ 1,130$ ) or more - irrespective of whether or not it is successful. German scientists are in effect being penalized for complying with the act by submitting moredetailed applications as part of the 'refinement' of animal research one of the '3Rs' criteria (see www. nc3rs.org.uk/the-3rs).

Such fees could push scientists to conduct their work abroad or deter them from doing animal experiments at all. This would be a disaster: the freedom of scientific research in Germany is as highly regarded as animal protection (Articles 5 and 20 of the Fundamental Law).

Michele Boiani, Alexandra Buehler Max Planck Institute for Molecular Biomedicine, Münster, Germany.

mboiani@mpi-muenster.mpg.de

\section{Too many mining disasters in Brazil}

Another mining dam collapsed in Brazil last month, bringing the country's total of these human and environmental disasters to more than 80 . With at least 600 mining dams still operating, the government urgently needs to evaluate the associated risks, tighten its mining code and enforce its safety law for dams.

The environmental effects reach beyond the pollution of fresh water, soils and coastal systems. Such accidents eradicate rare endemic species and disrupt ecological interactions, ecosystem functions and evolutionary processes (M. Lambertz and J. A. Dergam Nature 528, 39; 2015; J. Massante Nature 528, 39; 2015).

Those responsible for these dam accidents still go unpunished (R. Meira et al. Biodivers. Conserv. 25, 407-409; 2016). In our view, the most pervasive and systematic threats to Brazil's biodiversity are rooted in weak official policies and poor monitoring, management and legislation.

Three mining companies in Brazil have set up a US\$1.1-billion foundation to mitigate social, environmental and economic effects on the Rio Doce basin. But without policy reform, the ecological and social issues could dash Brazil's hopes of meeting the 2020 Aichi biodiversity targets (M. Di Marco et al. Conserv. Biol. 30, 189-195; 2016).

Alison Gonçalves Nazareno University of São Paulo, Brazil. Jean Ricardo Simões Vitule Federal University of Paraná, Brazil. alison_nazareno@yahoo.com.br 